\title{
The Eastern Cape labour market in transition: Key issues and debates
}

\author{
Geoffrey Wood \\ Department of Sociology and \\ Industrial Sociology \\ Rhodes University \\ GRAHAMSTOWN
}

\author{
Richard Haines \\ Department of Sociology \\ University of Port Elizabeth \\ PORT ELIZABETH
}

\begin{abstract}
The Eastern Cape labour market in transition: Key issues and debates

This study represents an assessment of key issues relating to the lahour market based on survey research conducted in an Eastern Cape secondary urban centre. This study was conducted at a time when South Africa was undergoing rapid social, economic and political transition. The primary focus of this study is on the specific implications of structural unemployment. Key sub-dimensions include the nature of divisions in the labour market, the extent of migrancy, survival strategies by the structurally unemploved, and perceptions of the union movement at a time when the latter's role has become increasingly institutionalised.
\end{abstract}

\section{Introduction}

This paper explores a number of key issues pertaining to the Eastern Cape labour market at a time when South Africa is facing far-reaching political and economic change ${ }^{14}$. Based on a survey conducted in Grahamstown, a secondary urban centre in the Eastern Cape, the central aims of the research were to assess the extent of structural unemployment, the major survival strategies of the jobless, and the relationship between un-

14 The findings of this study are more fully contained in the research report of Haines and Wood (1994) - "Aspects of the Eastern Cape Labour Market". 
The Eastern Cape labour market in transition: Key issues and debates

employment and divisions in the labour market. Particular attention was accorded to the connection between unionization and labour market segmentation. Although primarily the findings of a localised survey, this study covers issues of regional and national relevance, and, it is hoped, through assisting in the identification of some of the possibilities and restraints on reconstruction, may facilitate the formulation of policy alternatives.

This study falls within the realm of economic sociology, and focuses not only on the extent of unemployment and of formal divisions in the labour market, but also the cultural dimension (Holton, 1992:181), and focuses on the way in which individuals perceive and respond to these issues. It is recognized that the relationships outlined in this article are not purely static, but are interlinked, and form part of a series of interlocking variables and events (see Simmel, 1980:57-60).

\section{Method}

\subsection{Research methods}

The research method employed was a survey of adult members of the civilian labour force (18 years or over) resident in greater Grahamstown. The sample size represents a product of not only the overall size of the population, but also deviation in responses (Bailey, 1987:84-92). The sample size was computed after a pilot study had been conducted through simple quota sampling ${ }^{15}$. In addition, the pilot study greatly assisted in the formulation of the final interview schedule, and resulted in the elimination or modification of ambiguous or difficult-to-comprehend questions. The final survey was conducted through probability sampling, by means of the area sampling method. Area sampling can involve systematic sampling, where each unit constitutes a collection of elements. The advantage of systematic sampling is that the final sampling frame is drawn up during (rather than prior to) the interviewing process. This is of particular advantage in lower income areas, where accurate lists of the population are generally not available prior to commencing research. Interviews were

is Statistical tests revealed that the sample was representative of the population in the Grahamstown region. The final sample size was 166 respondents. 
conducted at the level of place of residence, rather than in terms of selected respondents' names (Bailey, 1987:87-88). The overall population was divided into a series of readily identifiable strata (upper-middle, middle, lower income formal settlements, informal settlements), defined in terms of different residential areas, in order to encompass a range of income levels. These constituted the primary sampling unit (PSU). Thereafter, trained interviewers selected respondents dwellings systematically.

It should be noted that the use of the above sampling method does have certain inherent limitations. Firstly, as places of residence, and not individuals' names were used, it was possible for the same respondent to be interviewed twice. To reduce the possibility of this occurring, interviews were conducted in as short a time as possible, during a week in July 1994. Secondly, each strata should be truly representative of the identified population.

The interviews were conducted by trained interviewers, fully conversant with the vernacular language, enabling respondents to answer questions in the manner in which they felt most comfortable. Following the conducting of the survey, the data was inputted into computer, using the statgraphics programme to enable the generation of graphs and cross-tabulations and the performance of limited statistical tests.

\subsection{Ethics and accountability}

Although survey research does not have the obvious ethical problems associated with experimental and observation based research techniques, it should be recognized that certain ethical issues are of importance. Personally administered interviews do involve a two-way relationship between the interviewer and the subject. Respondents were informed of the nature of the research, the reasons for the research, giving them the right to refuse to be interviewed (British Sociological Association Ethical Guidelines, in Harvey \& MacDonald, 1993:4). Respondents were given a contact telephone number, should they wish to make any further enquiries surrounding the study at any time (Bailey, 1987:431). Furthermore, respondents were given the undertaking that individual responses were strictly anonymous and confidential, to be used for overall statistical purposes only. Finally, it was recognized that the researchers have 
accountability to the greater community in the region. Interviewers offered to supply respondents with the full research findings on request.

\section{Migrancy, survival strategies and informal networks of support}

Numerous studies concerning the South African labour market in transition have already been conducted. However, in contrast to general studies dealing with overall demographic, employment and union trends (see, for example, Barker, 1992), this study focuses on the perceptions of an Eastern Cape community, and provides more detailed insights into some of the overall trends noted in the literature. In addition, it provides further insights into the actual operation of informal networks of support and the practical effects of structural unemployment and the broad divisions within the labour market.

\subsection{Extent and implications of structural unemployment}

Figure one depicts the job mobility of respondents. Only $20 \%$ of respondents had changed jobs since entering the labour market. Although this could indicate a high degree of job satisfaction, it is more likely that this reflects high levels of structural unemployment and an unwillingness to change jobs after securing a permanent position. Even those who were employed, regardless of income levels, demonstrated a limited proclivity to change jobs. As Van Aardt (1994:54) notes, at the pre-market level, educational discrimination has distorted the supply (and demand) for labour, in addition to the former effects of racial discrimination. A sizable segment of the labour market in the Eastern Cape form a grouping whose skills are either inadequate or obsolete, making it extremely difficult for them to ever find employment (see Dernberg \& McDougall, 1972:346).

\subsection{Survival strategies}

Respondents were questioned as to what they would do if they were unemployed (Figure 2). Interestingly, only a relatively small grouping (14\%) said that they would join the informal sector. For the purposes of this research, the informal sector of an economy can be conceptually separated from the formal sector on account of the manner in which a final product is produced and exchanged (Rogerson \& Preston-Whyte, 1991:3). 
Geoffrey Wood \& Richard Haines

Because 'informal sector' is a problematic concept in terms of a definition, it is often more feasible to regard it as a process. In the 1980s, government policy towards the informal sector shifted from a degree of ambivalence to being seen as a panacea for unemployment, a means of remedying economic decline, and in line with then privatization initiatives (Nattrass, 1990:218). This, in turn led to considerable euphoria over the informal sector's capacity to absorb the unemployed. However, it seems evident that in an area with a high level of structural unemployment, few seemed willing to pursue an informal sector career. In-depth interviews revealed mixed feelings on the sector. Whilst some argued that the sector provided a range of opportunities, and offered considerable flexibility, others pointed to the intense competition and often low returns of informal sector work. Although the informal sector does have the capacity to generate a living for the otherwise marginalized, its capacity should not be overestimated.

This seeming lack of interest in informal sector activity could reflect a lack of entrepreneurial sentiment that might be resolved through additional training programmes and/or incentives. Many theorists have suggested a direct linkage between socialization and entrepeneurism (see Tawney, 1961:312). The informal sector is an important generator of income, and has indeed increased black per capita income on a nation-wide basis (Van Aardt, 1994:47). However, it should be noted that the informal sector does have certain limitations: it is constrained by limited access to credit and its limited ability to compete with highly developed and competitive, mostly white owned manufacturers (Nattrass, 1990:218). As noted above, competition in the informal sector is intense, particularly in lower income areas, reflected by, inter alia, the endemic taxi wars in the region. The sector is characterized by low incomes and poor employment conditions (Van Aardt, 1994:47). It is thus extremely difficult for informal sector operatives to formalise their activities, heightening divisions in the labour market between the formally employed and the marginalised. Thus, limited interest in informal sector activity could be the product of a realistic assessment of that area to absorb additional numbers of the unemployed. Although the informal sector remains a major employer in the region, and indeed an area where a proportion of respondents looked to as a means for survival, by no means should it be viewed as the substitute 
The Eastern Cape labour market in transition: Key issues and debates

for more focused job creation and social upliftment programmes, involving both the state and the formal sector.

Twenty-one percent of the respondents said that they would wait until a suitable position should arise. This response reflects not only the limited opportunities available in the region, but also the debilitating effects of high levels of structural unemployment. As Van Aardt (1994:17) notes, existing high unemployment levels are exacerbated by the low labour absorbtion capacity of the formal sector, and a low production elasticity of employment. Should job seeking seem fruitless, a self-perpetuating situation arises, where individuals may no longer actively seek employment. Such workers can be said to constitute the discouraged unemployed, those who are often simply classified as "not in the labour force" (McConnell, 1981:177).

As Pateman (1970:104) notes, "we learn to participate by participating". Participating in the work environment is a self-reinforcing phenomenon. Those who are socialised in a work environment are indeed more likely to actively seek to participate in the future. As Carlton (1990:195) notes, socialization is ultimately about the perpetuation of values, a description of processes, and cannot determine the attitudes and values, which are a product of the environment itself. In an environment of high unemployment there may be a weaker perpetuation of a work ethic than in areas where employment rates are higher. In particular, attitudes to employment options are directly related to the existence of role models, and the actual alternatives available (Golan, 1981:55). Not only are there fewer role models in a region with chronically high unemployment, but there will also be a lower social stigma attached to being unemployed.

Most (54\%) of the respondents chose the migrancy option to leave the city to seek work elsewhere. It should be noted that this would represent only the one side of pressures impelling individuals towards migrancy, and that others within the region may opt to move to larger centres on account of 'pull factors', including declining social and economic costs of living in the larger urban centres (May, 1990:184).

Traditionally, the Eastern Cape has been a net exporter of labour. However, only seventeen percent of respondents had actually migrated in search of jobs at some stage. Nonetheless, it should be noted that such 
respondents represented temporary migrants who had since returned to Grahamstown, and the actual exodus to larger urban centres would be very much greater, enabled by the scrapping of influx control measures in the 1980s. However, internal migrancy in the Eastern Cape seems a popular option, probably on account of the shorter distances to travel, and the nature of informal mechanisms of support. The research revealed that informal mechanisms of support are highly developed in the region, and closely related to family structures. In major urban centres, such ties are likely to be considerably weaker.

Twenty-six percent of respondents reported that they had come to Grahamstown to seek employment. Considering the high levels of joblessness within this centre, this reflects not only the extremely dire circumstances prevalent within the neighbouring former homeland of the Ciskei, but also the effects of drought on neighbouring white farms, which has fnrced large numbers of former agricultural labourers into the city. Again, poverty may be somewhat alleviated through the existence of informal networks of support.

Almost half the respondents were unemployed and received some form of financial support from friends and relatives. This situation provides further evidence of the widespread prevalence of extended informal networks of support, particularly amongst those in lower income brackets (reflected, inter alia, in their category of residence). However, an even more remarkable finding was that fifty-two percent of respondents gave financial support to friends or relatives. In other words, many of those who were themselves unemployed and received financial assistance, still managed to provide some financial support to their dependants. Such money could be generated by episodic informal sector activity (as adverse to informal sector involvement as a full-time career), state remittances (e.g. pensions, disability allowances, unemployment insurance) and crime. The former may often be 'invisible' to outside researchers. In common with full-time informal sector activity, it is unrecorded and lacks accompanying social security benefits (Friedman \& Hambridge, 1991:164). Examples of such activities could include lending of goods, child-minding, renting of rooms and/or healing and praying, often tasks mostly performed by women (Friedman \& Hambridge, 1991:164). The 
importance of state remittances and petty crime as sources of income for the most marginalised should not be underestimated.

Despite this rather bleak situation, there was considerable optimism as to future prospects, particularly in the light of South Africa's political transition. Seventy-eight percent of respondents believed that job prospects would improve by the next elections (Figure 3). Most notably, almost all African National Congress supporters $(69 \%$ of the total number of respondents) believed this. It is evident that the senior governing party will face considerable pressure to improve the material circumstances of one of its key constituencies, those in the Eastern Cape. However, the very limited backing for other political actors, most notably the PAC, which, the survey revealed, had only $2 \%$ of support in the district, may result in voters having few alternatives to the ANC in 1999, even if their aspirations remain unfulfilled. Twelve percent of respondents supported the National Party, but very few of this grouping were Africans. In other words, although there are considerable demands being placed on the new government, it seems, short of a major political realignment, that residents in the district would be unlikely to voice their discontent through the ballot box, at least in the immediate future. Other mechanisms by which discontent could be voiced would include mass action, including stayaways, although the latter is obviously not an option for the structurally unemployed. The alternative could be a withdrawal from the political process which could enhance the marginalization of those on the peripheries.

\section{Unemployment and divisions in the labour market: Perceptions of the union movement}

During the 1980s, the independent trade unions assumed many of the characteristics of a social movement. Castells (Lowe, 1986:33) notes that social movements, in contrast to political parties, represent localised protest movements, seeking, inter alia, to bring about a more equitable society. Social movement trade unionism comes about when trade union leadership consciously seeks to break down barriers and build alliances with political groupings, thus transcending the orthodox nature of trade unionism (Lambert, 1988:34). Webster (1987:217) asserts that this situation came about as a result of the 1980s South African state's failure 
Geoffrey Wood \& Richard Haines

to politically incorporate the unions, as a result of its determination to exclude blacks from all meaningful political rights. Indeed, by 1988 , the unions represented the principal form of opposition to the then National Party government, seemingly not only representing their members, but all those political rightness or economically disadvantaged.

The unbanning of political organizations and the subsequent political settlement have led to the unions assuming a more secondary role. Coterminous with this has been a shift in the composition of the union movement, to representing increasingly skilled workers. It was revealed by a recent nation-wide survey of COSATU members conducted, inter alia, by the authors ${ }^{16}$, that the majority of members of that federation were, at least, semi-skilled. This survey demonstrates a dramatic shift in the labour market and the changing nature of the union movement. Hindson (1987:98-100) noted that the apartheid labour market was segmented between pass-bearing 'insiders' and 'illegal outsiders', as adverse to earlier racial divisions. In other words, the South African labour market was divided into a number of segments, with little mobility between them (Barker, 1992:15). It is possible that the division noted by Hindson could have been replaced by a new form of segmentation, between skilled, unionised 'insiders' and unskilled non-unionised 'outsiders' (see Webster, 1991:59). This situation raises the question as to how the unions are now perceived, especially by those in peripheral positions of the labour market. In other words, are they still seen as a mass social movement, voicing the concerns of a large grouping of society, or are they simply viewed as combinations of the skilled, leaving those who are unemployed and in less secure categories of employment rightness?

Most respondents either believed that the unions had not improved overall conditions of living, or were uncertain in this regard (Figure 4). Those in less secure categories of employment and the unemployed were particularly uncertain as to the benefits provided by the trade union movement. It is evident that the unions represent a very specific component of the labour market, and are seen by many as having limited impact in furthering their interests, despite the unions political role, and

16 Together with Janet Cherry, Dave Ginsburg, Gilton Klerck, Johann Maree, Roger Southall and Eddie Webster. 
more particularly the role of COSATU within the ANC alliance. Whilst the unions made an inestimable organizational contribution to the ANC alliance in the run-up to the elections, the ANC remains an extremely broad coalition, a coalition that can ill-afford to ignore the interests of its constituents that lack such an effective organizational voice. Recognizing this limitation, COSATU has made persistent efforts to organize unemployed workers. However, such initiatives have had very mixed results (Baskin, 1991:433). Somewhat more successful have been local civic-driven initiatives, in collaboration with local COSATU branches (Baskin, 1991:433). However, these attempts have yet to have a significant impact in the Eastern Cape region.

Twenty-one percent of respondents felt that the unions made a useful contribution in improving the material conditions of all, through bringing about general increases in real wages. In contrast, thirty percent felt that they effectively represented the interests of their members, and twelve percent that of employed workers. Meanwhile, six percent believed they only represented skilled workers. Thus, respondents were deeply divided in their perception of the union movement. Whilst a sizable grouping believed they had managed to improve general material conditions, more believed that they only represented their own members. Many were uncertain as to whose interests the unions represented. As Maasdorp (1992: 597) notes, labour market outsiders have a strong vested interest in keeping the labour market open and competitive, without a single grouping playing a restrictive role in their desire to maintain a relatively privileged position.

Respondents were similarly uncertain when asked whether they felt the unions were doing the best they could under the circumstances (Figure 5). Thus, as noted earlier, it is evident that whilst the unions have considerable political influence, forming a key component of the tripartite alliance, there are many who are uncertain about, or potentially hostile to the trade unions. Few other social groupings have such an effective internal democracy as the unions. Essentially, the situation is one of a potentially lop-sided civil society, where a sizable proportion of the government's constituency is not nearly as effectively represented, nor has the same capacity to bring its representatives to account as the unions, after all, a minority grouping. 
It was the young who had the highest expectations of an improvement in job prospects after the elections, although it should be noted that the majority of respondents in all age groupings believed the situation would get better (Table 1).

Table 1

\begin{tabular}{||l|l|l|l|l|}
\hline \hline $\begin{array}{l}\text { Job prospects improved } \\
\text { since elections }\end{array}$ & $\%$ Yes & \% No & $\begin{array}{l}\text { \% No } \\
\text { response }\end{array}$ & Totals \\
\hline Age & 100 & 0 & 0 & 5.4 \\
\hline$<18$ & 79 & 14.5 & 6.5 & 37.3 \\
\hline $18-25$ & 80.8 & 13.5 & 5.8 & 31.3 \\
\hline $26-35$ & 89.5 & 5.3 & 5.3 & 11.4 \\
\hline $36-45$ & 83.3 & 16.7 & 0 & 7.2 \\
\hline $46-55$ & 75 & 12.5 & 12.5 & 4.8 \\
\hline $56-65$ & 75 & 25 & 0 & 2.4 \\
\hline $65<$ & 81.9 & 12.7 & 5.4 & 100 \\
\hline Totals & & & & \\
\hline
\end{tabular}

Reflecting the prevailing demographic realities of the region, the largest group of respondents fell into the 18-30 years grouping. It should be noted that many of this grouping have never held formal employment. The above-mentioned nation-wide survey of union members revealed that 
relatively few were under the age of thirty five years. Although a national trend, statistical tests revealed that this process was particularly pronounced in the Eastern Cape.

These findings demonstrate that an entire generation has largely yet to be integrated into the formal labour market - an integration into those categories of employment where formal union membership is possible. Thus, again, it is outside of the union movement that certain expectations are the highest, a grouping that enjoys the least direct representation, yet is potentially the most powerful - those in less formal or temporary employment, the unemployed and those on the rural peripheries.

As noted above, it is evident that the majority of the members of the COSATU federation were, at least, semi-skilled. Table 2 compares employment status with perceptions as to whom the unions represented (percentages calculated vertically).

\section{Table 2}

\begin{tabular}{||l|l|l|l|l||}
\hline Employment status & $\begin{array}{l}\text { Em- } \\
\text { ployed }\end{array}$ & $\begin{array}{l}\text { Unem- } \\
\text { ployed } \\
\text { reprade unions }\end{array}$ & $\begin{array}{l}\text { No } \\
\text { response }\end{array}$ & Totals \\
\hline Skilled & 39.2 & 17.5 & 85.7 & 30.7 \\
\hline Union members & 3.8 & 10 & 0 & 6.6 \\
\hline All the employed & 25.3 & 36.3 & 0 & 29.5 \\
\hline Unemployed & 12.6 & 13.8 & 14.3 & 13.2 \\
\hline $\begin{array}{l}\text { Both the employed and } \\
\text { unemployed }\end{array}$ & 19 & 22.5 & 0 & 19.9 \\
\hline Totals & 47.6 & 48.2 & 4.2 & 100 \\
\hline
\end{tabular}

The relationship between the two variables was a statistically significant one. The most important finding is that the largest component of the employed (39\%) believe that the unions only represent skilled workers. In 
Geoffrey Wood \& Richard Haines

contrast, thirty-six percent of the unemployed believed that the unions represented all workers, although many $(23 \%)$ in the latter grouping thought that the unions represented all in the labour market.

Thus, it is evident that, in the light of trends in unionization, many of the employed saw the unions as coalitions of the skilled. There is little doubt that in terms of security of tenure and wage levels (in addition to a privileged bargaining position), trade union members constitute a relatively privileged grouping. It is also apparent that it was during the late 1970 s and early 1980s, when the independent unions rapidly expanded, that the skilling of the black labour force also largely took place. However, the question arises as to whether the principal line of segmentation is on skill, or the fact of union membership, the latter underlaid by the recruiting focus of the unions and the limits of trade union expansion. In the favour of the latter is that in those sectors where the unions are the strongest, they have been most successfully in compressing the pay gap between semi-skilled and unskilled workers (Wood, 1994:191). In other words, although the unions mostly represent those who are in some form of skilled category of employment, they remain highly effective in representing the interests of members who are in a less favourable position. This distinction could overshadow earlier divisions over migrancy versus settled labour, especially as over time, pure migrant labour tend to shift to semi-settled labour relations. However, the views of employed workers towards the unions reflect a disturbing trend, a trend which may well weaken the union movement in the future. Indeed, the character of the independent unions is already shifting, as a result of the rise of white collar unionism, most notably amongst civil servants in the former homelands.

Although the unions have a wide support base (indeed many of the unemployed saw them as ultimately improving their own $\operatorname{lot}^{17}$ ), it is evident that many of those respondents who had jobs saw them as only looking after certain categories of the employed. Indeed, the role of the unions seems to have become increasingly formalised. Whilst they may have the capacity to preserve high levels of internal democracy, there is

17 It was particularly the young who were sympathetic to the unions (Chi-square significance level 0.0138156). 
The Eastern Cape labour market in transition: Key issues and debates

little doubt that their character is rapidly shifting away from the broadlybased social movement role of the 1980s. Increasingly, the unions are representing a relatively privileged component of the labour market, and this will ultimately be reflected in the nature of the demands they put forward.

\section{Consequences of structural unemployment}

As Przeworski (1991:182) states, in a reformist transition of negotiated bargains it is necessary for the state to gain the co-operation of unions, opposition parties and other key stake holders in society. The reformist government is faced with the choice of mobilizing support for its policies from the unions, opposition parties, and other broadly based movements, or actively seek to undermine them. Whilst the unions constitute a component of the tripartite alliance, and opposition parties are included in the government of national unity, the structurally unemployed have very limited political influence. This exclusion could have seriously adverse consequences for new democratic institutions.

Przeworski (1991:181) identifies the trade union movement as a crucial partner in an accommodationist transition, as they are capable of mobilizing their constituents behind the government, and persuading their members to exercise wage restraint. However, the trade unions are only in a position to participate in pacts if they are relatively strong, broadly based, and politically influential. Attempts to draw the unemployed into the union movement, through unemployed workers unions, have been relatively unsuccessful. Whilst the independent unions have a dominant position amongst skilled workers, they lack support amongst the more marginal segments of the labour market. The labour 'market outsiders' of the region have very limited representation in other sectors of the current pacted national leadership. Unless visible attempts are made at grassroots level to improve the lot of the marginalised, and to give them a greater input into the transition process, the current political accommodationism may face serious challenges from below.

On the regional level, there is a real danger that the high levels of structural unemployment may be self-perpetuating. Those entering the labour market lack many role models, and, in the absence of other options, readily join the swelling ranks of the discouraged unemployed. Whilst the 
Geoffrey Wood \& Richard Haines

informal sector has some capacity to absorb the unemployed, this should not be overestimated. Indeed, the marginal nature of much informal sector activity is already apparent, in, inter alia, the endemic taxi wars in the region. Many respondents were active participants in extended informal networks of support. Such networks provide the means for physical survival for many in the region, and, indeed, shape patterns of migrancy. Internal migrancy within the region, whilst seemingly a less attractive option to movement to the major urban sector, represents a partial reflection of the operations of such networks.

\section{Conclusion}

Thus, a number of general trends are apparent with regard to employment and unemployment in the Eastern Cape.

* Firstly, the study revealed a high level of structural unemployment. A sizable proportion of this grouping are indeed discouraged unemployed - they are no longer actively seeking work.

* Secondly, it is evident that there are well developed, vigorous informal networks of support. Interestingly, these networks are not simply an informal mechanism of redistribution between the relatively privileged and the poor, but also between the most marginalised, the structurally unemployed. Sources of income for the latter range between episodic informal sector activity, state remittances, and, in some cases, crime.

Excluded from the formal economy, a central concem of RDP reconstruction should be to draw at least some of this structurally unemployed grouping into the broader productive economy. In addition to the direct benefits, this reconstruction will facilitate in the socialization of those who will enter the job market in the future, reinforcing a work ethic and providing role models and promoting creative thinking as career options.

* Thirdly, this study revealed that to many respondents the informal sector was a comparatively unattractive option to the unemployed. The latters' capacity to absorb new entrants to the labour market should not be overstated. It seems evident that much informal sector activity in the region is intensely competitive, and not always very 
The Eastern Cape labour market in transition: Key issues and debates

profitable. An alternative option, internal migrancy within this region of high unemployment seems again more a measure of last resort than a widely employed survival strategy. Of greater concern is that many respondents chose the option of inactivity in the event of unemployment - an option that could only increase marginalization and heighten divisions between the formally employed and the unemployed.

The role of the unions is a complex one. Although a broad based, and internally democratic social movement, a movement that, furthermore, enjoys considerable influence at governmental level, it is seen by many as only pursuing the interests of a minority. Indeed, many of the employed saw them as only looking after skilled workers. There is a direct relationship between skill, unionization and employment. The majority of respondents in the region can indeed be seen as labour market 'outsiders', with few prospects of becoming 'insiders' in the immediate future. These 'outsiders', in contrast to unionised 'insiders' lack an effective organizational base. In certain areas, however, they have higher aspirations, and form a large component of the senior goveming party's constituency. Although there does not seem a viable political alternative in the Eastern Cape, there are many ways in which the more marginalised could conceivably voice their socio-economic concerns.

\section{Bibliography}

BAILEY, K.D. 1987. Methods of Social Research. New York : The Free Press.

BARKER, F.S. 1992. The South African Labour Market: Critical Issues for Transition. Pretoria : Van Schaik.

BASKIN, J. 1991. Striking Back: A History of COSATU. Johannesburg : Ravan.

CARLTON, E. 1990. War and Ideology. London : Routledge.

DERNBERG, T. \& McDOUGALL, F. 1972. Macroeconomics: The Measurement, Analysis and Control of Aggregate Economic Activity. New York : McGraw-Hill.

FRIEDMAN, M. \& HAMBRIDGE, M. 1991. The Informal Sector, Gender and Development. (In Rogerson, C. \& Preston-Whyte, E. South Africa's Informal Economy. Cape Town : Oxford University Press. p. 161-186.)

GOLAN, N. 1981. Passing Through Transitions. New York : Free Press. 
Geoffrey Wood \& Richard Haines

HAINES, R. \& WOOD, G. 1994. Aspects of the Eastern Cape Labour Market: Aspirations, Hopes and Survival Strategies. Research Report. Port Elizabeth : University of Port Elizabeth.

HARVEY, L. \& MACDONALD, M. 1993. Doing Sociology. London : Macmillan.

HINDSON, D. 1987. Pass Controls and the Urban African Proletariat. Johannesburg : Ravan.

HOLTON, R. 1992. Economy and Society. London: Routledge.

LAMBERT, R. 1988. Political Unionism in South Africa. Johannesburg : University of Witwatersrand. (Ph.D. Thesis.)

LOWE, S. 1986. Urban Social Movements: The City after Castells. London : Macmillan.

MAASDORP, G. 1992. Meeting Expectations. (In Schrire, R. Wealth or Poverty: Critical Choices for South Africa. Cape Town : Oxford University Press. p. 584-607.)

MAY, J. 1990. The Migrant Labour System: Changing Dynamics in Rural Survival. (In Nattrass, N. \& Ardington, E. The Political Economy of South Africa. Cape Town : Oxford University Press. p. 175-186.)

McCONNELL, C. 1981. Economics: Principles, Problems and Policies. New York : McGraw-Hill.

NATTRASS, N. 1990. The Small Black Enterprise Sector - A Brief Note of Caution. (In Nattrass, N. \& Ardington, E. The Political Economy of South Africa. Cape Town : Oxford University Press. p. 217-228.)

PATEMAN, C. 1970. Participation and Democratic Theory. Cambridge : Cambridge University Press.

PRZEWORSKI, A. 1991. Democracy and the Market. Cambridge : Cambridge University Press.

ROGERSON, C. \& PRESTON-WHYTE, E. 1991. South Africa's Informal Economy, Past, Present and Future. (In Rogerson, C. \& Preston-Whyte, E. South Africa's Informal Economy. Cape Town : Oxford University Press. p. 1-8.)

SIMMEL, G. 1980. Essays in Interpretation in Sociology. Manchester : Manchester University Press.

TAWNEY, R.H. 1961. Religion and the Rise of Capitalism. Harmondsworth : Penguin.

VAN AARDT, K. 1994. The Future South Africa: Issues, Prospects and Options. Pretoria : Van Schaik.

WEBSTER, E. 1987. Introduction to the Labour Section. (In Moss, G. \& Obery, l. eds. SA Review 4. Johannesburg : SARS/Ravan. p. 209-248.)

WEBSTER, E. 1991. Taking Labour Seriously. South African Sociological Review, 4(1):50-72.

Koers 60(3) 1995: 381-400 



\section{FIGURE 2}

If unemployed, would

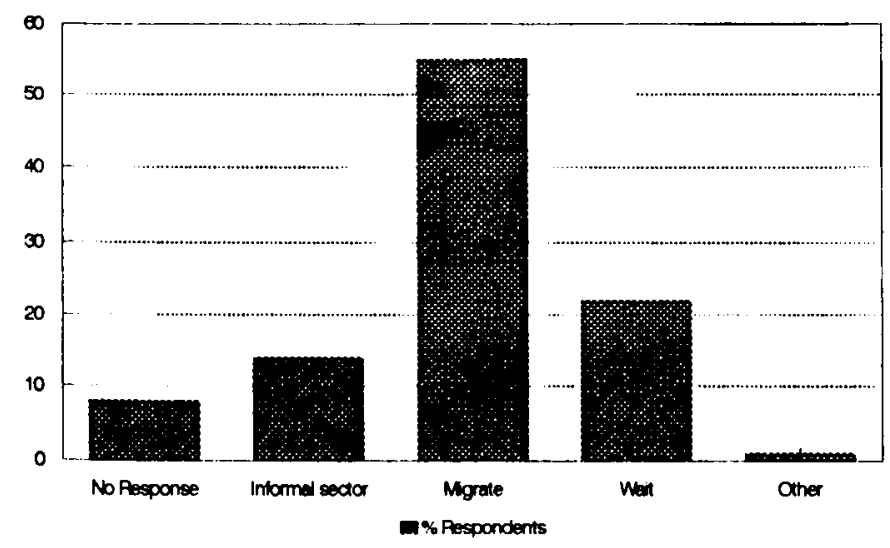

FIGURE 3

Job prospects improved since elections

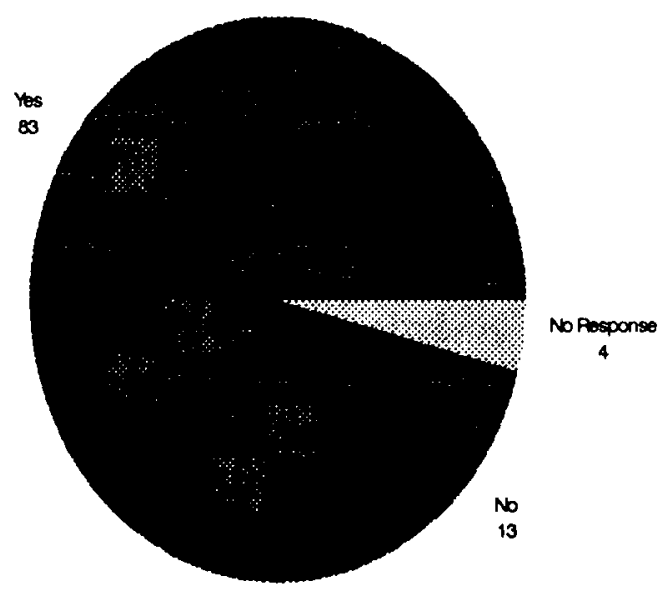




\section{FIGURE 4}

Trade unions improved living conditions

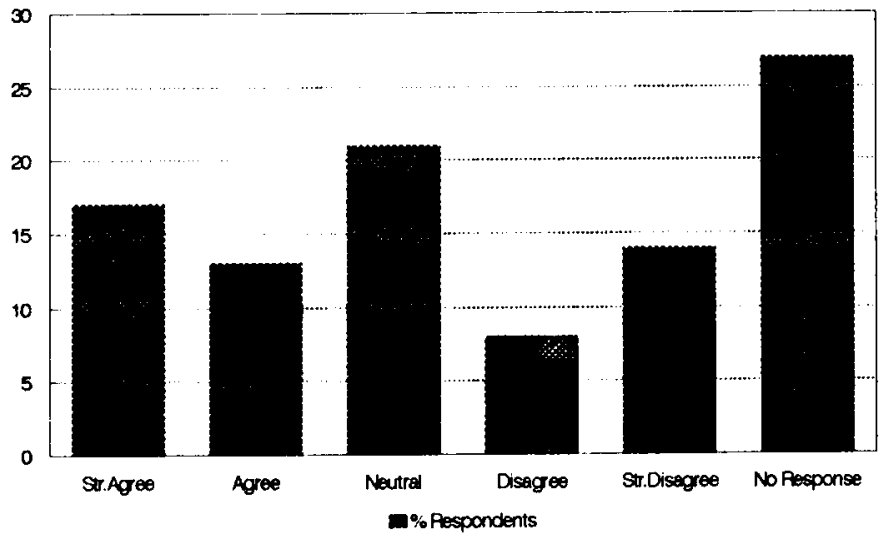

FIGURE 5

Trade unions doing best in circumstances

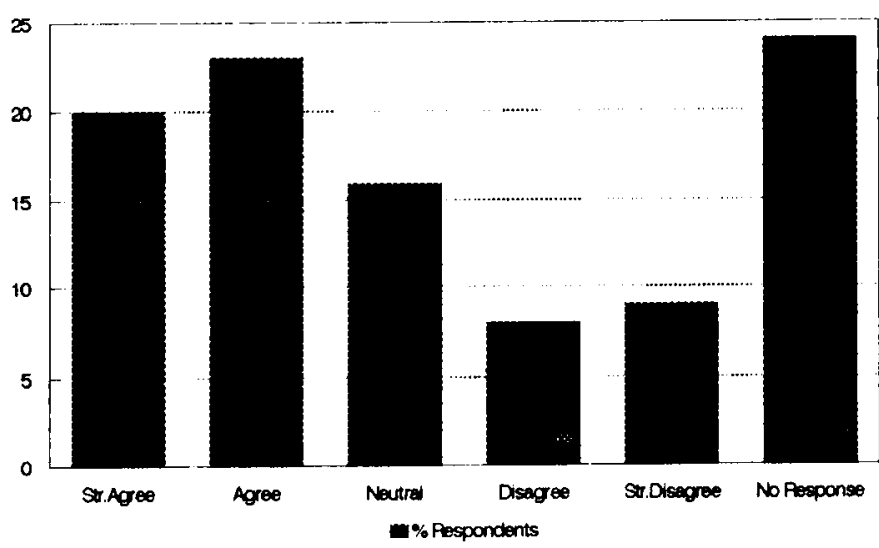

